\title{
An Energy Model for Adult Female Caribou of the Denali Herd, Alaska
}

\author{
RODNEY D. BOERTJE
}

\begin{abstract}
Estimates of the energy costs of resting, activity, and productive processes from the literature were applied to caribou activity budgets and movements documented during 1978-80 to estimate seasonal and annual energy requirements of adult female caribou (Rangifer tarandus granti) in Denali National Park and Preserve. Energy requirements were $45 \%$ lower in winter than summer, primarily because of a $21 \%$ reduction in resting metabolic rate and benefits of fat catabolism in winter, and high summer costs of lactation, fat deposition, and activity. Estimated energy requirements totaled 38.2 $\mathrm{MJ} \bullet$ day $^{-1}$ during the insect season, 36.7 during summer migration, 34.2 during fall migration, 31.9 during prerut and rut, 29.3 during calving and postcalving, 23.7 during early and late winter migrations, 21.6 during early winter, 20.9 during late winter, and 20.5 during midwinter. Annual energy requirements, including costs of pregnancy (368.6 MJ) and lactation (560.3), totaled $9,870 \mathrm{MJ}$, excluding costs of cratering through snow and apparently minor costs of physiological stress. Compared to studies of food energy requirements of penned caribou, the model gives accurate predictions of total metabolizable energy requirements when allowances are made for the relative inactivity of penned animals.
\end{abstract}

Modeling the energy requirements of an ungulate population is a prerequisite to estimating nutritional carrying capacities (Moen 1973, Robbins 1973, Wallmo et al. 1977, Mautz 1978). Measurements of the energy requirements of Rangifer have received emphasis in several studies (Makarova and Segal 1958, Hammel et al. 1961, Segal 1962, McEwan 1970, Luick et al. 1974, Young and McEwan 1975, White and Yousef 1978), but these measurements have not previously been used to model seasonal energy requirements of a caribou/reindeer (Rangifer tarandus) population.

\footnotetext{
Author is game research biologist, Alaska Department of Fish and Game, 1300 College Road, Fairbanks, Alaska 99701 . At the time of the research, author was graduate student, Alaska Cooperative Wildlife Research Unit, University of Alaska, Fairbanks.

Financial and logistical support was provided by the U.S. National Park Service (contract CX-9000-7-E080).

Manuscript accepted May 28, 1985.
}

Thomson (1977) attempted to model the year-round energy expenditure of wild reindeer in Norway using estimates of energy expenditure from the literature. However, Thomson's applications of energy costs differed in several ways from those presented here, making comparisons difficult. The most significant deviations included Thomson's exclusion of estimates for the calorigenic effect of food and his extremely high estimate for the energy cost of trotting. Gaare et al. (1975) also estimated seasonal energy requirements of wild reindeer in Norway. However, their estimates are about $45 \%$ of those reported here. Since they did not present energy-cost estimates of the various activities, it is impossible to account for the difference. White et al. (1975) estimated the summer energy requirements for caribou activity as simply $2 \times$ basal metabolic rate (BMR). However, they used a winter-BMR value, so their summer energy estimates are substantially lower than presented here.

I studied the Denali (formerly McKinley) caribou herd in Denali National Park and Preserve, Alaska during 1978-80. A model of the nutritional ecology of the herd was developed to assess the energetic/nutritional status of this extremely reduced population (Boertje 1981). This paper demonstrates the applicability of measurements of energy costs by modeling metabolizable energy requirements of adult female caribou in the Denali herd.

\section{Methods}

Blaxter (1962), Agricultural Research Council (1965), Moen (1973), Robbins (1973), and Weiner (1975) give the following basic formula for calculating energy requirements of ruminants:

$\begin{aligned} & \begin{array}{c}\text { Total daily } \\ \text { energy } \\ \text { requirement }\end{array}= \\ & \begin{array}{c}\text { Basal metabolic } \\ \text { energy expenditure } \\ \begin{array}{c}\text { Production costs } \\ \text { considering associated } \\ \text { efficiencies }\end{array}\end{array}+\begin{array}{c}\text { Activity } \\ \text { expenditure } \\ \text { Additional cost } \\ \text { to maintain } \\ \text { homeothermy }\end{array}\end{aligned}+$

JOURNAL OF RANGE MANAGEMENT 38(5), September 1985 
Several assumptions were made in consideration of this formula. It was assumed that no additional costs would be needed to maintain homeothermy among adult Denali caribou. Hart et al. (1961) found that a 9-month-old caribou exhibited no increase in metabolism (measured using a face mask) when ambient temperatures reached $-55 \mathrm{C}$. Temperat ures as low as $-55 \mathrm{C}$ are extremely rare on the wintering grounds of the Denali caribou herd. In cases where windchill could be detrimental to energy balance, caribou have access to sheltered hillsides and/or stands of spruce.

I also deviated from the above formula by using resting metabolic rate ( $R M R$ ), rather than $B M R$ or fasting metabolic rate (FMR), as a maintenance metabolic level and as a basis for calculating daily energy requirements. Values for RMR include the heat produced from digestive processes or the calorigenic effect of food, whereas measurement of BMR or FMR assumes standard conditions of fasting for 48 hours or more (post-absorptive state). Addition of the calorigenic effect of food to the energy model gives estimates of "metabolizable energy requirements," which includes total food energy requirements less the energy contained in the feces, urine, and methane. Metabolizable energy requirements were estimated throughout this paper, unless otherwise indicated.

BMR was used only to express daily energy requirements as multiples of BMR. McEwan's (1970) measurement of the metabolic rate of an adult female caribou, fasted for a 21-day period in February, is the only value approximating BMR in adult caribou. This value $\left(381 \mathrm{~kJ} \bullet \mathrm{kg}^{-0.75} \bullet \mathrm{day}^{-1}\right)$ was used to estimate winter BMR, and summer BMR was estimated as $482 \mathrm{~kJ} \bullet \mathrm{kg}^{-0.75} \bullet \mathrm{day}^{-1}$, which assumes that a $21 \%$ reduction occurs in adult female Rangifer metabolic rates from summer to winter.

Winter reductions in metabolic rates begin in November (McEwan and Whitehead 1970) and continue through May (McEwan 1970). Thus, "winter" as used in the model occurs from November to calving and "summer" from calving to November. The $21 \%$ seasonal reduction in metabolic rates was calculated by comparing average standing energy costs (includes maintenance costs) during summer and winter of adult female Rangifer (Table 1). These standing costs were considered equivalent to RMR.

Table 1 also presents energy costs of lying (includes maintenance costs) and the added energy costs (i.e., excluding maintenance costs) of a variety of activities and productive processes. Derivations of several of these energy costs are explained below.

Energy costs of white-tailed deer (Odocoileus virginianus) walking in snow (sinking depth of $23 \mathrm{~cm}$ ) were about $40 \%$ greater than walking on bare ground (Mattfield 1973). Energy costs of caribou walking in snow were estimated as only $15 \%$ greater than summer values by considering: (1) the larger hoof-foot area of caribou (lower foot loading) compared to white-tailed deer, (2) the singlefile strategy that caribou frequently exhibit when walking in deep, soft snow, and (3) the wind-swept snow conditions of most of the Denali herd's wintering area, with virtually no snow remaining. Energy costs of trotting/galloping in snow were also assumed to be $15 \%$ greater than summer values.

Energy costs of cratering in snow were estimated by subtracting the costs of foraging, standing, and walking from Makarova and Segal's (1958) measurements $(\mathbf{N}=27)$ of reindeer cratering and foraging for 2-to 90 -min periods in extreme snow conditions ( 80 to $90 \mathrm{~cm}$ deep, soft snow or compact, crusted snow about 30 to $35 \mathrm{~cm}$ in depth).

Energy cost of trotting/galloping at a mean speed of $12 \mathrm{~km}$. $\mathrm{hr}^{-1}$ (Thomson 1977) was estimated as $30 \mathrm{~kJ} \bullet \mathrm{kg}^{-1} \bullet \mathrm{hr}^{-1}$ from measurements reported in 3 studies. Mautz and Fair (1980) measured the energy cost of running for a white-tailed deer as 25 $\mathrm{kJ} \bullet \mathrm{kg}^{-1} \cdot \mathrm{hr}^{-1}$. White and Yousef (1978) developed equations for predicting the energy cost of reindeer walking for various speeds

Table 1. Estimates and measurements of energy costs of activities and productive processes used in the calculation of seasonal energy expenditure in adult female caribou. Only standing and lying values include maintenance costs.

\begin{tabular}{|c|c|c|c|}
\hline Activity & Season & Energetic cost & Reference \\
\hline \multirow[t]{2}{*}{ Standing } & Summer & $640 \mathrm{~kJ} \cdot \mathrm{kg}^{-0.75} \cdot \mathrm{day}^{-1}$ & $\begin{array}{l}\text { Segal (1962), Luick and White (1971), Young } \\
\text { and McEwan (1975), White and Yousef } \\
\text { (1978)-Rangifer }\end{array}$ \\
\hline & Winter & $505 \mathrm{kj} \cdot \mathrm{kg}^{-0.75} \cdot \mathrm{day}^{-1}$ & $\begin{array}{l}\text { Makarova and Segal (1958), McEwan } \\
\text { (1970)-Rangifer }\end{array}$ \\
\hline \multirow[t]{2}{*}{ Lying } & Summer & $582 \mathrm{~kJ} \bullet \mathrm{kg}^{-0.75} \bullet \mathrm{day}^{-1}$ & $\begin{array}{l}\text { Standing costs are } 10 \% \text { greater, White and } \\
\text { Yousef }(1978) \text {-reindeer }\end{array}$ \\
\hline & Winter & $459 \mathrm{~kJ} \bullet \mathrm{kg}^{-0.75} \bullet \mathrm{day}^{-1}$ & \\
\hline \multicolumn{2}{|c|}{ Lying to standing and return } & $0.10 \mathrm{~kJ} \bullet \mathrm{kg}^{-1}$ & Blaxter (1962)-cattle \\
\hline \multicolumn{2}{|c|}{ Rumination } & $0.13 \mathrm{~kJ} \cdot \mathrm{kg}^{-1} \cdot \mathrm{h}^{-1}$ & Osuji (1974)-sheep \\
\hline \multicolumn{2}{|l|}{ Foraging/eating } & $1.88 \mathrm{~kJ} \cdot \mathrm{kg}^{-1} \cdot \mathrm{h}^{-1}$ & Osuji (1974)-sheep \\
\hline Cratering & Winter & $0.94 \mathrm{~kJ} \bullet \mathrm{kg}^{-1} \bullet \mathrm{h}^{-1}$ & see Methods \\
\hline Walking (horizontal) & Summer & $2.30 \mathrm{~kJ} \cdot \mathrm{kg}^{-1} \cdot \mathrm{km}^{-1}$ & White and Yousef $(1978)^{1}-$ reindeer \\
\hline Walking in snow & Winter & $2.64 \mathrm{~kJ} \cdot \mathrm{kg}^{-1} \cdot \mathrm{km}^{-1}$ & see Methods \\
\hline \multicolumn{4}{|l|}{ Climbing (vertical) } \\
\hline \multicolumn{2}{|l|}{$+9 \%$ grade } & $31.0 \mathrm{~kJ} \cdot \mathrm{kg}^{-1} \cdot$ vert. $\mathrm{km}^{-1}$ & $\begin{array}{l}\text { White and Yousef }(1978)^{2}- \\
\text { reindeer }\end{array}$ \\
\hline \multicolumn{2}{|l|}{$-9 \%$ grade } & $-5.7 \mathrm{~kJ} \cdot \mathrm{kg}^{-1} \bullet$ vert. $\mathrm{km}^{-1}$ & $\begin{array}{l}\text { White and Yousef }(1978)^{2}- \\
\text { reindeer }\end{array}$ \\
\hline \multirow[t]{2}{*}{ Trotting/galloping } & Summer & $30 \mathrm{~kJ} \bullet \mathbf{k g}^{-1} \cdot \mathrm{h}^{-1}$ & see Methods \\
\hline & Winter & $35 \mathrm{kj} \cdot \mathbf{k g}^{-1} \cdot \mathrm{h}^{-1}$ & see Methods \\
\hline \multicolumn{2}{|l|}{ Hair growth } & $100 \mathrm{MJ} \bullet$ year & see Methods \\
\hline \multicolumn{2}{|l|}{ Lactation } & $560.26 \mathrm{MJ}$ per calf & see Methods \\
\hline \multicolumn{2}{|l|}{ Pregnancy } & $368.57 \mathrm{MJ}$ per calf & see Methods \\
\hline \multirow[t]{2}{*}{ Fattening } & Summer & $578.9 \mathrm{MJ}$ per summer & see Methods \\
\hline & Winter & $-365.0 \mathrm{MJ}$ per winter & see Methods \\
\hline
\end{tabular}

IValue was taken from reindeer walking on dry tundra and includes only the added cost of walking.

2Values include only additional costs of ascent or descent. 
and terrains. The equation for walking on dry tundra predicts an energy cost of $36 \mathrm{~kJ} \cdot \mathrm{kg}^{-1} \cdot \mathrm{hr}^{-1}$ at a speed of $12 \mathrm{~km} \bullet \mathrm{hr}^{-1}$. Measurements by Hammel et al. (1961), on a reindeer running and pulling a sled, averaged $29 \mathrm{~kJ} \cdot \mathrm{kg}^{-1} \cdot \mathrm{hr}^{-1}$.

To calculate energy costs of fattening, total body weight of adult female caribou in the Denali herd was assumed to fluctuate $10 \mathrm{~kg}$ annually, from $110 \mathrm{~kg}$ in autumn to $100 \mathrm{~kg}$ in spring (a $9 \%$ decrease from prime autumn weights). Data recorded by Skoog (1968) for 3to 5-year-old female caribou in interior Alaska support these figures. This annual fluctuation of about $10 \%$ autumn body weight was also noted by Steen (1968) in Scandinavia and Dauphine (1976) in central Canada.

To determine the energy required for this weight gain and the energy available from the winter loss in body weight, it was assumed that a $10-\mathrm{kg}$ decline in total body weight through the winter corresponds to a decline of about $10 \mathrm{~kg}$ in total body solids for unfasted Rangifer (R.D. Cameron, pers. commun.). Dauphiné (1976) stated that fluctuations in seasonal body weights of adult caribou are largely due to the deposition and mobilization of fat. Measurements of chemical body composition of adult female reindeer in March and August in Svalbard (Ringberg et al. 1980) indicated that $90 \%$ of the change in the solids of ingesta-free body weights was accounted for by changes in fat. Therefore, 1 considered the 10-kg change in body solids to be $90 \%$ fat and $10 \%$ protein. Robbins (1973) summarized calorific values of fat $(39.3$ $\left.\mathrm{kJ} \bullet \mathrm{g}^{-1}\right)$ and protein $\left(22.6 \mathrm{~kJ} \bullet \mathrm{g}^{-1}\right)$ for several ruminants. The efficiency of the utilization of metabolizable energy for fattening was estimated at $65 \%$ during lactation. This value is 14 percentage units higher than that predicted based solely on estimates of the metabolizable energy of the diet $\left(10.0 \mathrm{MJ} \bullet \mathrm{g}^{-1}\right.$, Boertje 1981) during fattening (Agricultural Research Council 1965). However, fattening costs estimated here apply primarily to lactating animals, and Moe et al. (1971) documented that the efficiency of the utilization of metabolizable energy is much higher for lactating than nonlactating animals.

Metabolizable energy requirements for the deposition of $9 \mathrm{~kg}$ of fat and $1 \mathrm{~kg}$ of protein is $578.9 \mathrm{MJ}(376.3 \mathrm{MJ} \div 0.65)$, or 5.41 $\mathrm{MJ} \bullet$ day $^{-1}$ when gaining weight at a rate of $93 \mathrm{~g} \bullet$ day $^{-1}$ during 16 July-30 October). The mobilization of the $10 \mathrm{~kg}$ of fat and protein $\left(51 \mathrm{~g} \cdot \mathrm{day}^{-1}\right)$ was assumed to be $97 \%$ efficient, which denotes a utilization of $364.3 \mathrm{MJ}$ or $1.84 \mathrm{MJ} \cdot$ day $^{-1}$ from body reserves during 1 December-16 June. Periods of fat storage and use were considered consistent with seasonal trends measured by Dauphiné (1976) in back, kidney, abdominal, and marrow fat in adult female caribou in central Canada.

Energy costs of lactation were estimated by combining measurements on the energy content of reindeer milk and the cost of its production (Luick and White 1971, Luick et al. 1974). Blaxter (1962), the Agricultural Research Council (1965), Moe et al. (1971), and Robbins (1973) discuss the efficiency of the utilization of metabolizable energy for lactation. I used an efficiency coefficient of $76 \%$ in May and June and $70 \%$ beginning $1 \mathrm{July}$, because fat reserves presumably would no longer be used for milk production after 1 July and because of the high metabolizable energy content of the spring and summer diets of Denali caribou (Boertje 1981). The gradual reduction in milk production documented by Luick et al. (1974) for reindeer was considered to calculate average daily energy costs of lactation for each season.

Metabolizable energy costs of pregnancy were calculated in $\mathrm{MJ}$ (y) up to any day (t) of the 227-day gestation period (Skoog 1968, McEwan and Whitehead 1972) using the following formula modified from Blaxtcr (1962):

$$
y=\left(7.24 e^{0.0174 t}\right)-7.367
$$

To derive this formula, a peak value of $5.8 \mathrm{MJ}^{\circ}$ day $^{-1}$ was used during the last 2 weeks of pregnancy. The peak value was calculated by assuming a proportional relationship between peak energy costs of pregnancy in a dairy cow (Agricultural Research Council 1965 ) and peak costs in caribou, based on a 22-kg birth weight in dairy cattle and 6-kg birth weight (Skoog 1968) in caribou. Metabolizable energy content of diets of the dairy cow and Denali caribou in winter were similar (Boertje 1981).

Annual energy costs of pelt growth in caribou was estimated as $0.82 \mathrm{MJ} \cdot$ day $^{-1}$ during 1 June-30 September. Robbin's (1973) measurements of the energy retained in the annual growth of the pelt in white-tailed deer were used and I assumed a $40 \%$ greater energy cost for caribou and an efficiency of utilization of metabolizable energy of $70 \%$ for hair production.

Activity budgets (the percent of time spent in various activities) and movement rates are from Boertje (1981). Energy costs for feeding include those associated with standing, foraging, and walking while feeding (at speed of $0.13 \mathrm{~km} \cdot \mathrm{hr}^{-1}$ ). Energy costs for walking ( $\left.3.22 \mathrm{~km} \cdot \mathrm{hr}^{-1}\right)$ and trotting/galloping include standing and movement costs, unless otherwise specified. Rumination time was assumed to be $50 \%$ of lying time (Thomson 1977).

Documentation of caribou activity budgets during migration periods and midwinter was limited due to caribou movements and weather. Therefore, activity budgets documented during the insect season, prerut and rutting season, early winter, and late winter were applied to the summer, fall, early winter, and late winter migrations, respectively, with allowances made for time spent migrating $\left(3.22 \mathrm{~km} \bullet \mathrm{hr}^{-1}\right)$. The midwinter activity budget was calculated by averaging early and late winter budgets.

\section{Results and Discussion}

Several factors influenced the marked seasonal differences in energy requirements (Fig. 1), including most notably the $21 \%$ reduction in standing costs (RMR) from summer to winter (Table 1). The high energy costs of lactation (Table 1) were most important during the calving and postcalving season (Table 2), but this high cost was compensated by the low proportion of time spent active and lack of fat deposition during this period, yielding intermediate energy requirements compared to low winter and high summer values (Fig. 1). The energy costs of pregnancy in late winter increased total energy requirements only slightly from midwinter as a result of reduced activity in late winter (Table 2). The highest energy requirements occurred during the insect season (Fig. 1) due to the high summer RMR, the high proportion of time spent active, and the high energy costs associated with lactation and fattening (Table 2). Summer migration values (36.66 MJ • day $^{-1}$ ) were also high (Fig. 1) due to the high costs of activity and lactation (Table 3), but deposition of fat reserves had not yet begun. Fall migration values $\left(34.25 \mathrm{MJ} \cdot\right.$ day $\left.^{-1}\right)$ decreased from the insect season (38.15 MJ $\bullet$ day $^{-1}$ ) due to a decrease in activity and a decline in lactation (Tables 2, 3). Fat deposition continued during the prerut and rut, but this coincided with a decline in lactation and activity costs (Table 2). Early and late winter migration values were nearly identical (Fig. 1); low activity costs and body weight in late winter were compensated by high pregnancy costs (Table 3 ).

Daily energy requirements ranged from $38.15 \mathrm{MJ}$ during the insect season to $20.54 \mathrm{MJ}$ during midwinter (Fig. 1), a $46 \%$ decrease. Variations in activity budgets accounted for a minimum seasonal difference of about $2 \mathrm{MJ} \bullet$ day $^{1}$, comparing early and late winter, and a maximum of $6 \mathrm{MJ} \bullet \mathrm{day}^{-1}$, comparing late winter and the insect season (Table 2). In comparison, fattening costs totaled $5.41 \mathrm{MJ} \bullet$ day $^{-1}$ during the insect season, lactation costs totaled $6.39 \mathrm{MJ} \cdot$ day $^{-1}$ during the calving and postcalving season, and pregnancy costs totaled $4.86 \mathrm{MJ} \bullet$ day $^{-1}$ during late winter migration. Cratering costs, when applied to proportions of the day spent grazing in winter, added about $1.2 \mathrm{MJ} \bullet$ day $^{-1}$, assuming cratering was prolonged and snow conditions severe. Cratering could, therefore, increase winter energy expenditure a maximum of about $5 \%$.

Changes in body weight also influenced seasonal differences in energy requirements. A $110-\mathrm{kg}$ caribou was estimated to expend about $2 \mathrm{MJ}$ more per day than a $100-\mathrm{kg}$ caribou during the same season. 
Table 2. Seasonal estimates 1 of daily metabolizable energy requirements of adult female carlbou in the Denall caribou herd, $1978-80$. The first 5 activities listed include maintemance costs.

\begin{tabular}{|c|c|c|c|c|c|c|c|c|c|c|c|c|}
\hline \multirow{4}{*}{ Body weight } & \multicolumn{12}{|c|}{ Season } \\
\hline & \multirow{2}{*}{\multicolumn{2}{|c|}{$\begin{array}{c}\begin{array}{c}\text { Calving and } \\
\text { postcalving } \\
(22 \text { May-30 June) }\end{array} \\
100 \mathrm{~kg}\end{array}$}} & \multirow{2}{*}{\multicolumn{2}{|c|}{$\frac{\begin{array}{c}\text { Insect } \\
\text { (16 July-31 Aug.) }\end{array}}{105 \mathrm{~kg}}$}} & \multirow{2}{*}{\multicolumn{2}{|c|}{$\begin{array}{c}\begin{array}{c}\text { Pre-rut and rut } \\
16 \text { Sep.-31 Oct.) }\end{array} \\
110 \mathrm{~kg}\end{array}$}} & \multirow{2}{*}{\multicolumn{2}{|c|}{$\frac{\begin{array}{c}\text { Early winter } \\
(16 \mathrm{Nov}-31 \mathrm{Dec} .)\end{array}}{110 \mathrm{~kg}}$}} & \multirow{2}{*}{\multicolumn{2}{|c|}{$\begin{array}{c}\begin{array}{c}\text { Midwinter } \\
\text { (1 Jan.-28 Feb.) }\end{array} \\
107 \mathrm{~kg}\end{array}$}} & \multirow{2}{*}{\multicolumn{2}{|c|}{$\begin{array}{c}\begin{array}{c}\text { Late winter } \\
\text { (1 Mar.-15 Apr.) }\end{array} \\
105 \mathrm{~kg}\end{array}$}} \\
\hline & & & & & & & & & & & & \\
\hline & $\%$ time & MJ & $\%$ time & $\mathbf{M J}$ & $\%$ time & $\mathbf{M J}$ & $\%$ time & $\mathbf{M J}$ & $\%$ time & MJ & $\%$ time & MJ \\
\hline \multicolumn{13}{|l|}{$\overline{\text { Activity }}$} \\
\hline Lying & 52 & 9.57 & 19 & 3.63 & 39 & 7.71 & 32 & 4.99 & 37 & 5.66 & 42 & 6.32 \\
\hline Standing & 3 & 0.61 & 25 & 5.25 & 12 & 2.61 & 8 & 1.37 & 5 & 0.85 & 2 & 0.33 \\
\hline Feeding & 37 & 9.42 & 33 & 8.74 & 40 & 11.00 & 48 & $\begin{array}{l}11.05 \\
(12.24)^{2}\end{array}$ & 50 & $\begin{array}{c}11.40 \\
(12.62)^{2}\end{array}$ & 53 & $\begin{array}{c}11.75 \\
(13.01)^{2}\end{array}$ \\
\hline Walking & 7 & 2.66 & 21 & 8.33 & 7 & 2.69 & 11 & 4.40 & 8 & 2.96 & 4 & 1.52 \\
\hline Trotting/galloping & 0.9 & 0.65 & 1.7 & 1.29 & 1.2 & 0.95 & 0.4 & 0.37 & 0.2 & 0.23 & 0.1 & 0.09 \\
\hline Ruminating & 26 & 0.08 & 10 & 0.03 & 20 & 0.07 & 16 & 0.06 & 18 & 0.06 & 21 & 0.07 \\
\hline \multicolumn{13}{|l|}{ Lying to standing } \\
\hline and return & $18^{3}$ & 0.18 & $10^{3}$ & 0.11 & $22^{3}$ & 0.24 & $10^{3}$ & 0.11 & $12^{3}$ & 0.13 & $14^{3}$ & 0.15 \\
\hline Ascent & $0.10^{4}$ & 0.31 & $0.32^{4}$ & 1.04 & $0.08^{4}$ & 0.27 & $0.05^{4}$ & 0.17 & 0.044 & 0.14 & $0.03^{4}$ & 0.10 \\
\hline Descent & $0.10^{4}$ & -0.06 & $0.32^{4}$ & -0.19 & $0.08^{4}$ & -0.05 & $0.05^{4}$ & -0.03 & 0.044 & -0.02 & $0.03^{4}$ & -0.02 \\
\hline Lactation & & 6.39 & & 3.69 & & 0.55 & & 0 & & & & 0 \\
\hline Pregnancy & & 0 & & 0 & & 0.15 & & 0.38 & & 0.97 & & 2.41 \\
\hline Fattening & & -1.15 & & 5.41 & & 5.41 & & -1.24 & & -1.84 & & -1.84 \\
\hline Hair growth & & 0.62 & & 0.82 & & 0.29 & & 0 & & 0 & & 0 \\
\hline \multicolumn{13}{|l|}{ Totals } \\
\hline$\left(\mathrm{MJ} \bullet \mathrm{day}^{-1}\right)$ & & 29.28 & & 38.15 & & 31.89 & & 21.63 & & 20.54 & & 20.88 \\
\hline $\begin{array}{l}\text { Totals } \\
\left(\mathbf{k J} \bullet \mathbf{k j}^{-0.75} \bullet \text { day }^{-1}\right)\end{array}$ & & 926 & & 1,163 & & 939 & & 637 & & 617 & & 637 \\
\hline Multiple of BMR & & 1.92 & & 2.41 & & 1.95 & & 1.67 & & 1.62 & & 1.67 \\
\hline
\end{tabular}

1Migration periods (Table 3) are excluded from this table.

${ }^{2}$ Values include cratering costs in extreme snow conditions.

'Number of events.

${ }^{4}$ Units are vertical $\mathrm{km} \bullet$ day $^{-1}$.

Energy costs of physiological stresses from insect harassment (exclusive of increased observed activity), predators, humans, and heavy parasite loads (particularly infestations of oestrid fly larvae) were not included in the model. Blaxter (1962) indicated that nervousness and increased muscular tension accounted for a $10 \%$ increase in fasted metabolic rates of untrained versus trained sheep. Thus, if caribou experienced stress for an average of 2 $\mathrm{hr} \cdot$ day $^{-1}$, they would require only an additional $76 \mathrm{MJ}$ annually, less than $1 \%$ of the annual energy requirement. This suggests that physiological stresses from predators and insects have only a minor influence on the energy requirements of caribou/reindeer.
McEwan (1970) reported that the maintenance digestible energy intake (DEI) in 2 penned, adult female caribou averaged $665 \pm 18$ $\mathrm{kJ} \cdot$ day $^{-0.75} \cdot$ day $^{-1}$ from February to May. Converting to metabolizable energy intake (MEI $=0.82 \times \mathrm{DEI}$, Agricultural Research Council 1965), a value of $545 \mathrm{~kJ}^{\circ} \mathbf{k g}^{-0.75} \cdot$ day $^{-1}$ is obtained $(1.43$ $X$ winter BMR). The model gives a value of about $652 \mathrm{~kJ} \cdot \mathbf{k g}$ 0.75 day $^{-1}(1.71 \times$ winter BMR) for free-ranging caribou during the same period, assuming the caribou is not pregnant and is feeding on a maintenance diet as in McEwan's study. In a separate study, McEwan and Whitehead (1971) calculated the mean DEI of 11 pregnant reindeer and caribou fed ad libitum over the entire

Table 3. Estimates of daily metabolizable energy requirements (MJ) of adult female caribou in the Denall caribou herd during migration periods, $1978-80$.

\begin{tabular}{|c|c|c|c|c|}
\hline & $\begin{array}{c}\text { Summer } \\
\text { migration } \\
\text { (1 July-15 July) }\end{array}$ & $\begin{array}{c}\text { Fall } \\
\text { migration } \\
\text { (1 Sep.-15 Sep.) }\end{array}$ & $\begin{array}{c}\text { Early winter } \\
\text { migration } \\
\text { (1 Nov. } 15 \text { Nov.) }\end{array}$ & $\begin{array}{c}\text { Late winter } \\
\text { migration } \\
\text { (16 Apr.-21 May) }\end{array}$ \\
\hline Body weight & $105 \mathrm{~kg}$ & $110 \mathrm{~kg}$ & $110 \mathrm{~kg}$ & $100 \mathrm{~kg}$ \\
\hline \multicolumn{5}{|l|}{ Processes } \\
\hline Activity ${ }^{1,2}$ & 24.70 & 24.38 & 21.32 & 16.20 \\
\hline Migration ${ }^{2}$ & $\begin{array}{c}4.78 \\
(140 \mathrm{~km})\end{array}$ & $\begin{array}{c}1.78 \\
(50 \mathrm{~km})\end{array}$ & $\begin{array}{c}2.05 \\
(60 \mathrm{~km})\end{array}$ & 2.62 \\
\hline Ascent & 0.78 & 0.17 & 0.15 & $\begin{array}{c}(200 \mathrm{Km}) \\
0.20\end{array}$ \\
\hline Descent & -0.13 & -0.04 & -0.05 & -0.04 \\
\hline Lactation & 5.58 & 1.73 & 0 & 0 \\
\hline Pregnancy & 0 & 0 & 0.22 & 4.86 \\
\hline Fattening & 0 & 5.41 & 0 & -0.17 \\
\hline Hair growth & 0.82 & 0.82 & 0 & 0 \\
\hline $\begin{array}{l}\text { Totals } \\
\left(\mathbf{M J} \bullet \text { day }^{-1}\right)\end{array}$ & 36.66 & 34.25 & 23.69 & 23.67 \\
\hline $\begin{array}{l}\text { Totals } \\
\left(\mathbf{k J} \bullet \mathbf{k g}^{-0.75} \bullet \text { day }^{-1}\right)\end{array}$ & 1,118 & 1,008 & 697 & 749 \\
\hline Multiple of BMR & 2.32 & 2.09 & 1.83 & 1.97 \\
\hline
\end{tabular}

Activity costs include costs of the first 7 actions listed in Table 2. Activity costs for migration periods were assumed equal to activity costs of prior or following seasons (Table 2) with allowances for time spent migrating $\left(3.22 \mathrm{~km} \cdot \mathrm{hr}^{-1}\right)$

${ }^{2}$ Values include maintenance costs. 


\section{Estimated Daily Energy Expenditure (MJ)}

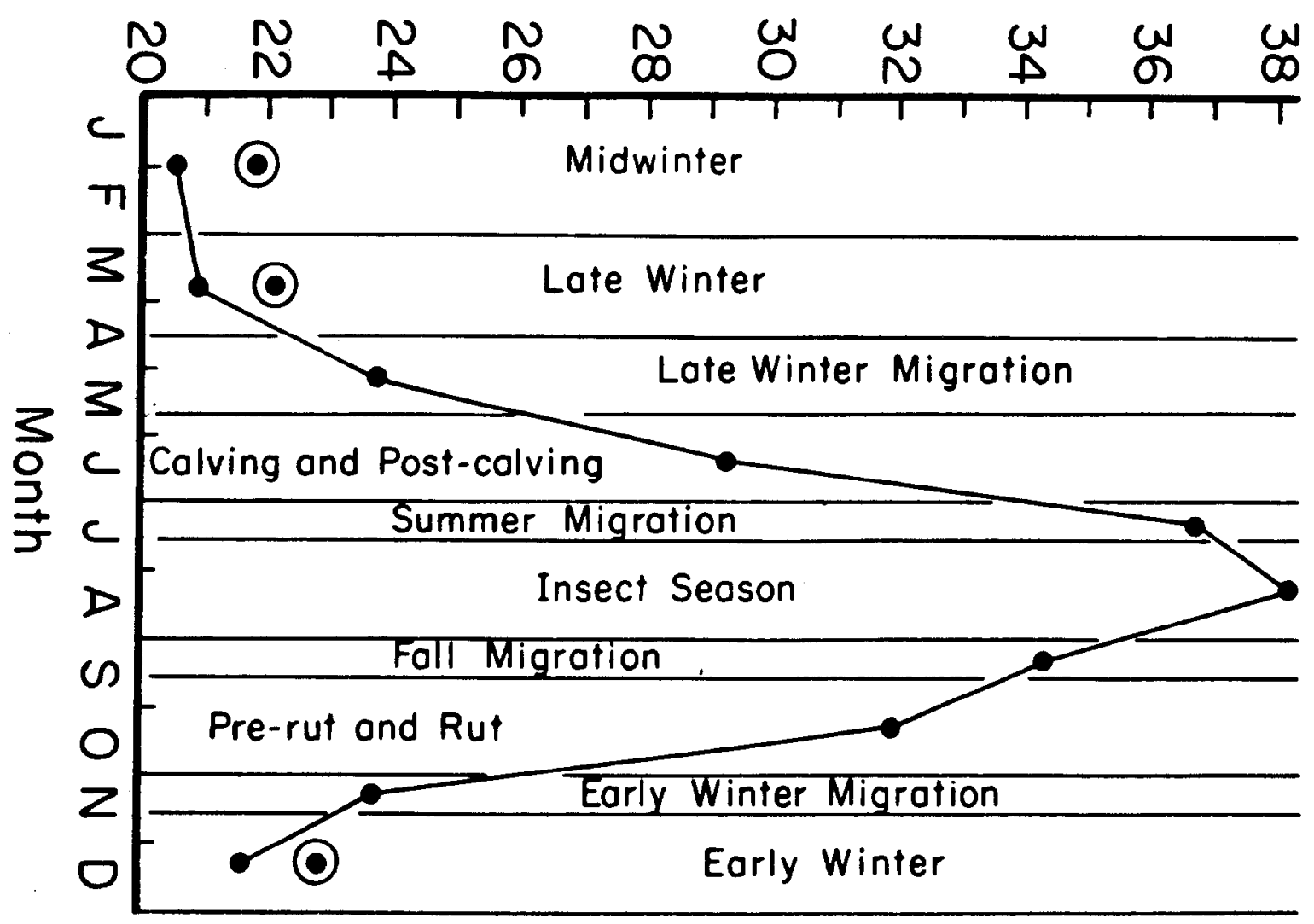

Fig. 1. Seasonal estimates of daily energy requirements of an adult female caribou with calf, Denali herd, 1978-80. Circled values include foraging costs in extreme snow cover conditions, compared to foraging in the absence of snow.

gestation period. The average MEI in these experiments was $571 \mathrm{kj}$ ${ }^{-0.75} \cdot \mathrm{day}^{-1}(1.50 \times$ winter BMR). I calculated a mean value of about $683 \mathrm{~kJ} \cdot \mathrm{kg}^{-.75} \cdot \mathrm{day}^{-1}(1.79 \times$ winter BMR for free-ranging caribou during the same period, including pregnancy costs.

Both comparisons indicate that free-ranging caribou require $20 \%$ more metabolizable energy in winter than penned caribou/reindeer, excluding costs of cratering. This $20 \%$ difference is easily accounted for by adding activity costs to McEwan's animals, which were in small pens during his experiments.

\section{Conclusions}

Total annual energy requirements for an adult female caribou, including costs of pregnancy $(368.57 \mathrm{MJ})$ and lactation (560.26 $\mathrm{MJ}$ ) totaled $9,870 \mathrm{MJ}$ (excluding costs of cratering and apparently minor costs of physiological stress). If cratering costs are added throughout winter, caribou may require $10,050 \mathrm{MJ}$ annually, assuming extreme snow conditions. Increased cratering activities would likely increase the proportion of time spent active (Bergerud 1974), therefore annual energy costs may reach $10,300 \mathrm{MJ}$. However, caribou would likely react to excessive energetic stress by reducing activity in late winter (Roby 1980).

Compared to studies of food energy requirements of penned caribou, the model gives accurate predictions of total metabolizable energy requirements when allowances are made for the relative inactivity of penned animals. Despite this agreement, parts of the model may over- or underestimate energy costs while other parts compensate for these errors. Accumulation of data on autumn fat deposition and winter fat loss in Alaska caribou is particularly needed to test assumptions in this model.
Uses of this model include: (1) testing the effects of a variety of energy-related variables on the seasonal or annual energy budget, (2) comparing energy expenditure among herds given differences in activity, body size, movements, seasons, and/ or degree of fattening, and (3) serving as a basis for modeling a population's nutritional ecology.

\section{Literature Cited}

Agricultural Research Council. 1965. The nutrient requirements of farm livestock. No. 2. Agr. Res. Coun., London.

Bergerud, A.T. 1974. Relative abundance of food in winter for Newfoundland caribou. Oikos 25:379-387.

Blaxter, K.L. 1962. The energy metabolism of ruminants. C.C. Thomas, Springfield, Ill.

Boertje, R.D. 1981. Nutritional ecology of the Denali caribou herd. M.S. Thesis. Univ. Alaska. Univ. Microfilms. Ann Arbor, Mich. (Master's Abstr. 13-18, 103).

Dauphine, T.C. 1976. Growth, reproduction and energy reserves. Part 4. Biology of the Kaminuriak population of barren-ground caribou. Can. Wildl. Serv. Rep. Ser. No. 38. Ottawa.

Gaare, E., B.R. Thomson, and O. Kjos-Hanssen. 1975. Reindeer activity on Hardangervidda. p. 206-215. In: F. E. Wielogolsaki (ed), Fennoscandian tundra ecosystems. Springer-Verlag, New York.

Hammel, H.T., T.R. Houpt, K.L. Anderson, and S. Skjenneberg. 1961. Thermal and metabolic measurements on a reindeer at rest and in exercise. Arctic Aeromedical Lab. Rep. AAL-TDR-61-54. Seattle, Wash.

Hart, J.S., O. Heroux, W.H. Cottle, and C.A. Mills. 1961. The influence of climate on metabolic and thermal responses of infant caribou. Can. J. Zool. 39:845-856. 
Luick, J.R., and R.G. White. 1971. Food intake and energy expenditure of grazing reindeer. p. 103-107. In: The structure and function of the tundra ecosystem, U.S. Tundra Biome Program, U.S. Int. Biol. Program. Univ. Alaska, Fairbanks.

Luick, J.R., R.G. White, A.M. Gau, and R. Jenness. 1974. Compositional changes in the milk secreted by grazing reindeer. I. Gross composition and ash. J. Dairy Sci. 57:1325-1333.

Makarova, A.R., and A.N. Segal. 1958. Physiological characteristics of the winter grazing of the reindeer. Opyt Isucheniya Regulyatsii Fisiologicheskii Funktsii (Experimental Research on the Regulation of Physiological Function) 4:29-35. Transl. from Russian by the Can. Wildl. Serv., Ottawa.

Mattfield, G.F. 1973. The effect of snow on the energy expenditure of walking in white-tailed deer. Northeast Fish and Wildl. Conf. Trans. 30th Northeast. Sect. of the Wildl. Soc. 30:327-343.

Mautx, W.W. 1978. Nutrition and carrying capacity. p. 321-348. In: J.L. Schmidt and D.L. Gilbert (eds), Big game of North America: ecology and management. Stackpole Books, Harrisburg, Pa.

Mautz, W.W., and J. Fair. 1980. Energy expenditure and heart rate for activities of white-tailed deer. J. Wildl. Manage. 44:333-342.

McEwan, E.H. 1970. Energy metabolism of barren-ground caribou. Can. J. Zoo. 48:391-392.

McEwan, E.H., and P.E. Whitehead.1970. Seasonal changes in the energy and nitrogen intake in reindeer and caribou. Can. J. Zoo. 48:905-913.

McEwan, E.H., and P.E. Whitehead. 1972. Reproduction in female reindeer and caribou. Can. J. Zoo. 50:43-46.

Moe, P.W., H.F. Tyrrell, and W.P. Flatt. 1971. Energetics of body tissue mobilization. J. Dairy Sci. 54:548-553.

Moen, A.N. 1973. Wildlife ecology. Freeman Co., San Francisco.

Osuji, P.O. 1974. The physiology of eating and the energy expenditure of the ruminant at pasture. J. Range Manage. 27:437-443.

Ringberg, T., E. Reimers, and R. S $\phi$ rumgard. 1980. Growth and seasonal change in organ weights and carcass composition of Svalbard reindeer (Rangifer tarandus platyrhyncus). p. 333-340. In: E. Reimers, E. Gaare, and S. Skjenneberg (eds), Proc. 2nd Int. Reindeer/Caribou Symp., R $\phi$ ros, Norway, 1979. Direktoratet for vilt og ferskvannsfisk, Trondheim.
Robbins, C.T. 1973. The biological basis for the determination of carrying capacity. Ph.D. Thesis. Cornell Univ., Ithaca.

Roby, D. 1980. Winter activity of caribou on two arctic ranges. p. 537-544. In: E. Reimers, E. Gaare, and S. Skjenneberg (eds), Proc. 2nd Int. Reindeer/Caribou Symp., Rфros, Norway, 1979. Direktoratet for vilt og ferskvannsfisk, Trondheim.

Segal, A.N. 1962. The periodicity of pasture and physiological functions of reindeer. p. 130-150. In: Severnyiolen'v Kerel'skoi ASSR. Acad. Nauk. SSSR, Moscow. Transl. by Can. Wildl. Serv., Ottawa.

Skoog, R.O. 1968. Ecology of the caribou (Rangifer tarandus granti) in Alaska. Ph.D. Thesis. Univ. Calif., Berkeley.

Steen, E. 1968. Some aspects of the nutrition of semi-domestic reindeer. p. 117-128. In: M.A. Crawford (ed), Comparative nutrition of wild animals. Academic Press, New York.

Thomson, B.R. 1977. The behavior of wild reindeer in Norway. Ph..D Thesis. Univ. Edinburgh, England.

Wallmo, O.C., L.H. Carpenter, W.L. Regelin, R.B. Gill, and D.L. Baker. 1977. Evaluation of deer habitat on a nutritional basis. J. Range Manage. 30:122-127.

Weiner, J. 1975. Model of the energy budget of an adult roe deer. Polish Ecol. Stud. 1:103-119.

White, R.G., and M.K. Yousef. 1978. Energy expenditure in reindeer walking on roads and on tundra. Can. J. Zoo. 56:205-223.

White, R.G., B.R. Thomson, T. Skogland, S.J. Person, D.E. Russell, D.F. Holleman, and J.R. Luick. 1975. p. 151-201. In. J. Brown (ed), Ecological investigations of the tundra biome in the Prudhoe Bay region. Biol. Pap. Univ. Alaska, Spec. Rep. No. 2.

Young, B.A., and E.H. McEwan. 1975. A method for measurement of energy expenditure in unrestrained reindeer and caribou. p. 355-359. In: J.R. Luick, P.C. Lent, D.R. Klein, and R.B. White (eds), proc. Ist Int. Reindeer/Caribou Symp. Biol. Pap. Univ. Alaska, Spec. Rep. No. 1. Fairbanks. 